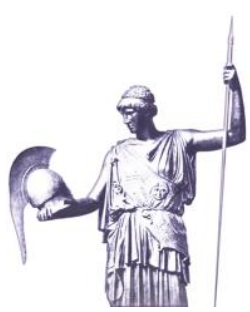

Connections: The Quarterly Journal

ISSN 1812-1098, e-ISSN1812-2973

А.Ш. Корвайа, Б. Джерадж и У.М. Боргофф, Connections QJ 15, № 1 (2016): 89-120 http://dx.doi.org/10.11610/Connections.rus.15.1.06

\title{
Подъем учебных программ по вопросам разведки: модель для Германии?
}

\section{Алесандро Шефлер Корвайа, Бригита Джерадж и Уве М. Боргофф}

Университет Бундесвера, Мюнхен; Директор Кампусного центра перспективного обучения, Мюнхен, Германия, https://www.unibw.de

Резюме: Исследования по вопросам разведывательной деятельности стали обычным предметом в высшем образовании в англоязычном мире. До сих пор в Германии не предлагались специализированные программы в этом направлении. Программа для аспирантов, в которой ставится ударение на понимание роли и контекста разведывательной работы, которая расширяет аналитические умения и углубляет квалификацию в области этой материи, могла бы сочетать лучшие черты разных образовательных моделей и внесла бы реальный вклад в создании кадрового резерва из высоко квалифицированных профессионалов в области разведки. В этом исследовательском докладе авторы сжато документируют состояние данной учебной дисциплины, приводят примеры из двенадцати аспирантских программ и дают начальный вариант программы по исследованиям в сфере разведывательной деятельности для университетов Германии.

Ключевые слова: исследования по вопросам разведывательной деятельности, учебная программа, военное образование.

\section{Введение}

По традиции университеты уделяют мало внимания вопросам разведывательной деятельности. Даже те ученые и институты, которые специализируются по вопросам национальной безопасности и обороны, только ограниченно занимаются проблемами разведки. По словам сэра Александра Кадогана, «исследования по вопросам разведывательной деятельности» представляют собой «отсутствующее измерение» в исследованиях по меж- 
дународным вопросам. ${ }^{1}$ Ситуация начала слегка изменяться в 1980-х и 1990-х: расследования в таких связанных с самими высокими кругами скандалами как Уотергейт и Иран-Контрас, рассекречивание все большего объема разведывательной информации в Соединенных Штатах и в Объединенном Королевстве привели к расширению осведомленности о важной роли разведки в международных делах. Появились первые ассоциации историков разведки и первые специализированные журналы. ${ }^{2}$

Однако, интерес к этой прежде малоизвестной дисциплине взрывообразно возрос только после событий от 11 сентября 2001 года: тогда как в 2006 году, к примеру, только четыре из двадцати пяти топ-университетов в Соединенных Штатов предлагали курсы по разведывательной проблематике, сейчас такие курсы есть в половине этих университетов. ${ }^{3}$ В то же время, курсы и даже специальные программы по вопросам разведки начали предлагать также университеты во Франции, Израиле, Испании и других странах. Движущими силами этого развития были исследователи, разведывательные агентства и ученые. В академических средах обширные последствия таких провалов разведки, как 9/11 и последовавшее вторжение в Ирак, разожгли исследовательский интерес к разведке в качестве важного и все еще недооцененного фактора национального процесса принятия решений. В то же время, сами разведывательные службы начали анализировать эти провалы и адаптировали обучение своих оперативников и аналитиков. ${ }^{4}$ Что касается студентов, публичность предмета и перспективный рынок труда, сопровождающие расширение деятельности разведывательных агентств, привлекает все больше и больше студентов, заинтересованных в карьере в сфере разведки - и в образовании, которое подготовит их наилучшим образом для нее.

В недавнем обзоре положения дел в этой сфере, ее наиболее выдающиеся представители пришли к согласию, что в течение последнего десятилетия эта дисциплина подверглась процессу профессионализации и утвердила себя как общепринятая субдисциплина в исследованиях по безопасности. Наиболее важными областями, изучаемыми этой дисциплиной, являются такие разнообразные темы, как неуспехи разведки, политизация разведки, вопросы контроля, этика разведывательной работы и связь меж-

1 Цитировано в Len Scott and Peter Jackson, "The Study of Intelligence in Theory and Practice," Intelligence \& National Security 19:2 (2004): 140.

2 Martin Rudner, "Intelligence Studies in Higher Education: Capacity-Building to Meet Societal Demand," International Journal of Intelligence and Counter-Intelligence 22:1 (2008): 112.

3 Jonathan Smith, "Amateur Hour? Experience and Faculty Qualifications in U.S. Intelligence Courses," Journal of Strategic Security 6:3 (2013): 25.

4 К примеру, разведывательное сообщество США создало «Центры квалификации» в четырех университетах. С тех пор их число увеличилось до десяти. Смотри Rudner, "Intelligence Studies," 114. 
ду национальной и разведывательной культурой. 5 Эта оценка процветающей дисциплины разведывательных исследований, однако, верна только для англоязычного мира. Она совершенно не соответствует состоянию в Германии, где разведывательная тематика остается почти несуществующей сферой. ${ }^{6}$

Большое число студентов, желающих сделать карьеру в сфере разведки, привело к появлению «разведывательных школ», особенно в Соединенных Штатах. Тогда как «Исследования в сфере разведывательной деятельности» как традиционная университетская дисциплина предназначена для студентов, интересующихся разведкой, разведывательные школы имеют более практическую направленность и пытаются давать образование будущим сотрудникам разведывательных организаций - в частности, аналитикам. ${ }^{7}$ Вместо того, чтобы создавать специалистов, которых затем разведывательные службы будут нанимать из-за их знаний, эти программы - которые на аспирантском или на магистерском уровне ${ }^{8}$ - сфокусированы на функциональных знаниях и должны давать образование "универсалам», которые обучены методам и механике разведывательного анализа. ${ }^{9}$ В результате проводимых в этих школах исследований, предмет разведывательного анализа постепенно превращается в отдельную субдисциплину в этой области.

5 Loch J. Johnson and Allison M. Shelton, "Thoughts on the State of Intelligence Studies: A Survey Report," Intelligence and National Security 28:1 (2013): 111.

6 Как подмечено одним из немногих ученых в этой сфере, Вольфгангом Кригером, это отсутствие является результатом в основном трех конкретных факторов: отсутствию рассекреченных документов, полному отсутствию бывших сотрудников разведки в университетах - как часть общего отсутствия так называемого «круговорота кадров», - и особенное мышление академической среды в Германии, которое характеризуется неким презрением к исследованиям по вопросам обороны и безопасности. Влияние истории двух тоталитарных режимов также означает, что это пренебрежение особенно сильно в отношение разведки. Смотри: Wolfgang Krieger, "German Intelligence History: A Field in Search of Scholars," Intelligence and National Security 19:2 (2004): 187-189.

7 Stephen Marrin, Improving Intelligence Analysis: Bridging the Gap Between Scholarship and Practice (Routledge: London, 2011), quoted in Michael Landon-Murray, "Moving U.S. Academic Intelligence Education Forward: A Literature Inventory and Agenda," The International Journal of Intelligence and Counter Intelligence 26:4 (2013): 746.

8 Для целей этого доклада программы разделены на бакалаврские, магистерские и аспирантские. Бакалаврские программы дают бакалаврскую степень. Магистерские программы задуманы как «последовательные» и не требуют существенного предшествующего профессионального опыта работы. Хотя в США и Объединенном королевстве в принципе нет четкой грани между «магистерскими» и "аспирантскими» программами, в этой статье мы будем называть аспирантскими (профессиональными) программами те программы, которые предназначены для практиков со значительным профессиональным стажем в этой сфере. Докторские программы в этом докладе не рассматриваются.

9 Landon-Murray, "Moving U.S. Academic Intelligence Education Forward," 746. 


\section{Университетское образование в сфере разведывательной деятельности?}

Это приводит нас напрямую к наиболее спорным и важным вопросам в дисциплине: что конкретно могут и должны предлагать университеты разведывательному сообществу в смысле образования? Как было сказано выше, основным традиционным каналом, посредством которого университеты обслуживают потребности разведывательных служб, была подготовка специалистов - политологов, инженеров или лингвистов. Такое образование получали обычно до поступления в соответствующие службы. Требуемая подготовка для конкретных задач затем имела место не в университетах, а в засекреченной среде внутриведомственных институций разведывательных служб.

Появление программ со специфически разведывательным содержанием в бакалаврских и магистерских курсах, в частности в разведывательных школах, уже меняет эту схему. Выпускники этих программ располагают меньшими специализированными знаниями и большим количеством практической подготовки и практических умений. Полезность этих программ является предметом споров, причем критики подчеркивают более важное значение знаний и экспертизы по конкретным дисциплинам в сравнении с «практической подготовкой» в аналитическом ремесле. Как говорит Ловенталь, «аналитиков нанимают за массу знаний, не за набор умений». ${ }^{10}$ Другие ведущие эксперты, наоборот, утверждают, что такие программы имеют существенное значение и предоставляют уникальные ресурсы разведывательному сообществу. ${ }^{11}$ Другим обсуждаемым вопросом является негомогенный характер и качество этих программ, что может быть нормальным для новой дисциплины. Как можно увидеть, степень, в которой характеристика кандидатов, которые университеты поставляют разведывательным агентствам, должна меняться, остается важным вопросом в данной сфере - компромисс между экспертизой в области, с одной стороны, и общая подготовка по важным разведывательным технологиям, с другой, остается наиболее спорной проблемой. ${ }^{12}$

Изменения происходят и в сфере последипломного образования, и его роль в карьере сотрудников разведки становится все более значительной. В свете множества провалов разведки, имевших место в начале 2000-х, многие разведывательные службы начали считаться с мнением их аналитических сообществ. Хотя расследование нападений 9/11 все еще сфокусировано на отсутствии межведомственного сотрудничества разведывательных служб, уже есть жалобы на разведывательных аналитиков, кото-

10 Mark M. Lowenthal, "The Education and Training of Intelligence Analysts," in Analyzing Intelligence: National Security Practitioners' Perspectives, ed. Roger Z. George and James B. Bruce (Washington, DC: Georgetown University Press, 2014), 306.

11 Landon-Murray, "Moving U.S. Academic Intelligence Education Forward," 768.

12 Относительно более детального обсуждения, см. там же. 
рые страдали «отсутствием воображения» и которым надо было выходить за рамки традиционных схем мышления. ${ }^{13}$ Но основной удар по разведывательному анализу был нанесен, когда расследование провалов разведки в Ираке вывело анализ в свет прожекторов. ${ }^{14}$ Доклады о неуспехах разведки обращали внимание на отсутствие аналитических стандартов, вину за что некоторые возлагали на факт, что «разведывательные аналитики проходят подготовку для соответствующей разработки теоретических схем и гипотез для проверок и по современным аналитическим методам общественных наук». ${ }^{15}$

Действительно, многие начали рассматривать всю сферу обучения и образования как самую большую профессиональную слабость анализа. ${ }^{16} \mathrm{~B}$ результате все больше подвергалось сомнению то, создает ли обучение в собственных институциях разведывательных служб достаточную интеллектуальную гибкость для того, чтобы выпускники справлялись с вызовами сложной современной среды угроз, и на самом ли деле внутреннее обучение в засекреченной среде действительно способствует достаточной аналитической тщательности и вдумчивости. Таким образом, традиционное разделение труда между разведывательными службами и университетами стало объектом сомнений, и разведывательные службы начали обдумывать, какую роль могли бы играть университеты в улучшении квалификации их аналитиков. В то время как университеты по традиции были ограничены до предоставления кандидатов для карьеры офицера разведки, службы начали воспринимать их и как возможные места для последипломного образования. Таким образом, образование рассматривалось как одно из средств для устранения отсутствия аналитических стандартов, на которое возлагали вину за неуспехи разведки.

И все-таки, что могли бы действительно предложить университеты в смысле последипломного образования - в частности, по сравнению с внутриведомственным обучением, при котором аналитики могут использовать их собственные системы и секретные материалы? По мнению Гудмана, академические институции имеют два фундаментальных преимущества в образовании в сравнение с закрытым внутриведомственным обучением: участие в исследованиях - и таким образом, доступ к самому современному учебному содержанию - и возможность знакомиться с критиче-

13 Относительно дискуссии о требованиях к разведке в сложной современной среде угроз, смотри Warren Fishbein and Gregory Treverton, "Making Sense of Transnational Threats," Kent Center Occasional Papers 3:1 (2004), доступно на https://www.cia.gov/library/kent-center-occasional-papers/index.html.

14 Roger Z. George and James B. Bruce, Analyzing Intelligence: Origins, Obstacles and Innovations (Washington, DC: Georgetown University Press, 2008), 5.

15 Michael W. Collier, "A Pragmatic Approach to Developing Intelligence Analysts," Defense Intelligence Journal, Joint Military Intelligence College Foundation 14:2 (2005): 21.

16 Lowenthal, "The Education and Training of Intelligence Analysts," 303. 
скими и неортодоксальными точками зрения. По словам Фрериха и Ди Риенцо, последипломные программы могут обеспечить «эпизодическую встряску в образовании», которая необходима для того, чтобы избежать «ограничения в одной эпистемологии, одной точке зрения и одном подходе к пониманию разведывательной деятельности». ${ }^{17}$ Университеты предлагают оптимальную возможность для такой встряски, и поэтому могут играть важную роль в предохранении профессионалов разведки от классических аналитических ловушек, на которых они часто не обращают внимание в своей ежедневной работе. Кроме того, такие программы так же предлагают форум, на котором представители отдельных частей разведывательного сообщества могут обмениваться мнениями о своем понимании разведки. Это позволяет этим офицерам задумываться над своей собственной ролью и способствует пониманию необходимости сотрудничества с другими частями «системы» разведки. ${ }^{18}$

\section{Подходы к учебным планам по исследованиям в сфере разве- дывательной деятельности}

Как на практике выглядят такие университетские программы? В этом разделе рассматривается вопрос, как программы додипломного и последипломного образования структурированы в смысле учебного содержания, основываясь на обзоре двенадцати программ, чье описание и учебное содержание можно найти в приложении. Указана также и дополнительная литература, в частности Руднер (2008) и Ландон-Муррей (2013).

Согласно Стаффорду Томасу, дисциплину «Исследования в сфере разведки» можно в целом разделить по применяемому подходу: функциональный, исторический/биографический, структурный и политический. Тогда как функциональный подход занимается такими фундаментальными способностями, как анализ и оценка, исторический/биографический подход изучает историю институций и личностей. Структурный подход исследует организацию и юридическую рамку разведывательных служб, а политический на первом месте занимается использованием разведки должностными лицами, определяющими политику и взаимодействием между политикой и разведкой. ${ }^{19}$

Как было сказано выше, дисциплина «Исследования в сфере разведки» сначала установилась в Англосфере. Тем не менее, существуют значитель-

17 Rebecca L. Frerichs and Stephen R. Di Rienzo, “Establishing a Framework for Intelligence Education and Training," Joint Force Quarterly (JFQ) 62 (2011): 72.

18 Смотри: Michael S. Goodman and David Omand, "What Analysts Need to Understand: The King's Intelligence Studies Program," Studies in Intelligence 52:4 (2008): 1-12 (выдержки, декабрь 2008; оригинальная версия засекречена). Сравни с Landon-Murray, "Moving U.S. Academic Intelligence Education Forward," 744-776.

19 Stafford T. Thomas, "Assessing Current Intelligence Studies," International Journal of Intelligence and Counterintelligence 2:2 (1988): 217-244. 
ные различия между Соединенными Штатами и Объединенным Королевством. В плане бакалаврских программ, хотя отдельные модули по этому предмету существуют, на магистерском уровне программы по разведке в Объединенном Королевстве часто являются просто вариантами более широких программ по международным отношениям. Даже в таких институтах, как Кингс-колледж, который также предлагает программы профессиональной квалификации для британских разведывательных служб, степень магистра по разведывательной проблематике и международной безопасности отличаются только по одному обязательному направленному на изучение разведывательной деятельности модулю от более широкой степени по военным исследованиям. Этот модуль сфокусирован на уроках исторических случаев, что свидетельствует о том, что в Объединенном Королевстве исследования в сфере разведывательной деятельности появилась как отдельная дисциплина, отделившаяся от исторических исследований. $^{20}$ Магистерская степень по разведывательным исследованиям, согласно британской модели, таким образом, является расширенной магистерской программой по международной истории или международным отношениям, и сфокусирована на специальных знаниях. ${ }^{21}$ Даже когда программа имеет существенной разведывательное содержание, основной целью таких классических университетских программ является подготовка ученых - а не практиков - по вопросам разведки. ${ }^{22}$

В Соединенных Штатах ситуация совершенно различная. Структура бакалаврских программ США, которые обычно включают изучение множества предметов, разделенные на основные и специализирующие, означает, что студенты могут сочетать специализацию по разведывательным исследованиям, к примеру, с основной специальностью по иностранному языку, политологии или экономике. Тогда как основная специальность дает знания по основному предмету, специализация по разведывательным исследованиям часто сфокусирована на необходимом наборе умений. $^{23}$ Такие программы особенно распространены в разведывательных школах, которые отражают американскую традицию профессиональных школ, примером чему являются школы по публичной администрации, в которых преподают как теоретики, так и практики данной профессии. В сфере последипломного образования программы в США могут быть гораздо более ориентированы на разведывательную проблематику, чем в

20 Scott and Jackson, "The Study of Intelligence in Theory and Practice," 141.

21 Относительно более подробного описания британских программ по разведывательной проблематике, смотри описание программ в Приложении.

22 Смотри, к примеру, учебный план Университета Аберистуита.

23 Относительно примера типичной специализации, смотри описание программы Университета Миссисипи в Приложении. Национальный университет разведки предлагает подобную, так называемую бакалаврскую программу для четвертого года, куда студенты поступают с трехлетним образованием из других колледжей и проходят один год ориентированного на разведку образования в НУР. 
Объединенном Королевстве, и часто являются отражением курсов, преподаваемых в рамках специализации по разведывательным исследованиям. Многие профессиональные школы, которые предлагают очень хорошо воспринимаемые, ориентированные на практиков программы по международным делам, к примеру, Университет Джорджтауна, так же предлагают те же программы с разведывательной спецификой. Хотя они сочетают разведывательную тематику с другими предметами - как и в Объединенном Королевстве - фокус на умениях остается основным отличием в этом плане.

Программы последипломного и профессионального образования в Объединенном Королевстве и США существуют как бы в своей отдельной реальности. Поскольку они предназначены для сотрудников разведки, которые уже считаются специалистами с существенным опытом в этой проблематике, в их содержании удается избежать многих из подводных камней, которые характерны для бакалаврских и магистерских программ. В частности, противоречие между «специальными» и «функциональными» знаниями становится менее важным для аналитиков, которые в некоторой степени уже обладают и теми, и другими. В институтах разведывательных служб, например, в Национальном университете разведки (являющегося частью Разведывательного управления Министерства обороны США), последипломные программы, специализирующиеся на разведке, обычно сочетают четыре характеристики: фундамент, умения, сильная концентрация изучения конкретных примеров и, наконец, диссертация на соискание степени магистра. В фундаментальной части этих курсов преподаются элементы международных отношений и безопасности, роль разведки, юридические рамки и организационные структуры соответствующих служб. Это тот спектр вопросов, который в наибольшей степени соответствует британским программам и которого можно было бы назвать «исследованиями в сфере разведки». В категории умений - т.е. функциональный подход ${ }^{24}$ - преподается, в основном, разведывательный анализ, с упором на анализ технологий, будущего и сценариев. Это спектр вопросов, который, главным образом, соответствует курсам, предлагаемым в разведывательных школах и в таких неакадемических институтах, как Университет ЦРу. ${ }^{25}$ Целью этих модулей чаще является не преподавание отдельных техник, а лучшая оценка ограничений и рисков. Такие программы соответствуют программам, по которым в Федеральной службе разведки Германии преподается то, что в других странах называется «критическим мышлением». Как ни странно, тогда как такие модули мало присутствуют в британских магистерских программах, они имеют место в курсах, предлагаемых в программах последипломного профессионального образования

24 Thomas, "Assessing Current Intelligence Studies," 239.

25 Хотя нет подробного описания в открытых источниках, Ловенталь упоминает о существовании таких программ в Университете ЦРУ. Смотри Lowenthal, "The Education and Training of Intelligence Analysts." 
в Объединенном Королевстве: закрытый, десятинедельный модуль, предлагаемый в Королевском колледже, предназначенный исключительно для сотрудников британских разведывательных служб, ориентированный главным образом на аналитические умения. ${ }^{26}$ и последнее, такие программы характеризуются сильной и очень конкретно ориентированной концентрацией на такие темы, как киберисследования или исследования в определенных областях. Целью этих узкоспециализированных тем является актуализация подготовки специалистов, обычно сфокусированных на областях, в которых университет располагает особой компетентностью. ${ }^{27}$ Почти все программы заканчиваются подготовкой диссертацией, учитывая то, что американские университеты не всегда требуют написания диссертации для завершения учебного плана. ${ }^{28}$

\section{Учебные планы по разведывательной проблематике в универ- ситетах Германии}

Как было показано в этом докладе, исследования в сфере разведывательной деятельности в качестве академической дисциплины и исследовательской программы сфокусированы на разведывательный аспект других исследуемых объектов, и во все большей степени на исследованиях в сфере профессиональных умений, необходимых для работы в секторе разведки - в частности, подобласти анализа в сфере разведки. Область разведывательных исследований установилась как все более распространенная академическая дисциплина и программы курсов в университетах, особенно в США и Объединенном Королевстве. В этом докладе также излагается мнение, что данный предмет является наиболее подходящим для последипломных программ на получение профессиональной степени. Для подготовки к карьере в разведывательных службах, и в частности, в аналитической сфере, бакалаврское образование, которое снабжает кандидатов знаниями по данному предмету, более важно, чем обучение для усваивания общих умений, которое может быть нужно для самых разнообразных карьер в разведывательном секторе. Подобным образом, обучение начинающих офицеров разведки лучше оставить закрытым школам служб разведки, где они могут проходить подготовку с реальными системами, которые они будут использовать, и могут иметь доступ к секретным ресурсам.

26 Goodman and Omand, "What Analysts Need to Understand," 2.

27 Относительно более детального обсуждения учебных планов по разведывательной тематике в США, смотри: Landon-Murray, "Moving U.S. Academic Intelligence Education Forward," 768-769.

28 International Affairs Office, U.S. Department of Education, "Structure of the U.S. Education System: Master's Degrees," February 2008, доступно на www2.ed.gov/ about/offices/list/ous/international/usnei/us/master.doc (по состоянию на 15 февраля 2016). 
В то же время, в докладе рассматривается то, что успех разведывательных исследований в англоязычном мире до сих пор не нашел своего отголоска в Германии. Хотя разведывательные службы Германии располагают своими кафедрами при Федеральном университете прикладных административных наук (Hochschule des Bundes Fachbereich Nachrichtendienste), они сфокусированы на бакалаврском образовании для общих сотрудников для должностей среднего уровня. ${ }^{29}$ В некоторой степени, существование такой программы устраняет необходимость в похожих бакалаврских программах в регулярных публичных университетах. В магистерской и последипломной области нет похожих программ. Это особенно примечательно, так как многие из причин, которые заставили разведывательные службы США и Объединенного Королевства создать последипломные программы в последние годы, имеют место и в Германии. Так же, как и в этих странах, от большинства офицеров - особенно занимающих высокие должности ожидается, что они приходят в свою службу с необходимыми умениями и получают мало дополнительной подготовки, если вообще получают, впоследствии (за исключением по техническим дисциплинам). В Германии также «аналитик в сфере разведки» является весьма редкой профессией. Аналитиков берут на работу за их опыт в определенной области - или просто назначают «аналитическую повинность» как часть карьеры “универсалиста» - большая часть последующей подготовки, которую они получают, сфокусирована на подготовке разведывательных продуктов и на работе с базами данных, а не на аналитических методах. Соответственно, очень вероятно, что обычные проблемы разведки - например, отсутствие общих аналитических стандартов - процветают в таких службах.

Можно ли создать последипломную профессиональную программу по разведывательным исследованиям в немецком университете и кто должен быть идеальным кандидатом для обучения по такой программе? Возможно, что это будут не студенты, стремящиеся к карьере в сфере разведки, а офицеры разведки среднего уровня с несколькими годами профессионального стажа. ${ }^{30}$ Как должен выглядеть учебный план для такой последипломной программы для получения профессиональной степени? Сравнимые программы в Объединенном Королевстве и в США сфокусированы на четырех аспектах: основы, умения, избранные темы и дипломная работа. Подобной структуре можно следовать и в программе для немецких университетов.

29 Должности среднего уровня (gehobener Dienst) сравнимы с должностями уоррент-офицеров. Хотя этот корпус очень опытен и исключительно квалифицирован, его карьерное развитие ограничено до средних уровней менеджмента (сравнимого с ротными офицерами).

30 Сравнимая магистерская степень в сфере стратегической разведки и стратегической технологической разведки в Национальном университете разведки имеет средний возраст обучаемых в 37 лет, тогда как программа в Королевском колледже предназначена для «старших аналитиков». 
Блок «основ» может рассматривать контекст, в котором функционирует разведка. Он мог бы включать курсы по глобальной политической среде и наиболее важные тенденции в экономике и технологии. Ему так же следовало бы включать конкретнее такое связанное с разведкой содержание, как роль разведки среди других элементов национального могущества, а также юридические и этические аспекты разведки. Таким образом, целью фундаментального блока было бы введение участников - многие из которых, возможно, работали в очень узком поле деятельности в предшествовавшие годы - в глобальные, макро-уровневые процессы и их влияние на разведку и национальную безопасность. Это дало бы им возможность заглянуть за рамки своей специализации в службе на более общие проблемы в области разведки. По окончание этого блока участники должны получить комплексную картину глобальной среды и роли разведки в ней. Этот блок должен быть похожим на основную программу в Национальном университете разведки, в котором «основная программа должна помочь студентам развить глобальную осведомленность и понимание того, как исторический, культурный, политический и социальные контексты оказывают влияние на разведку и национальную безопасность». ${ }^{31}$

Второй блок развития умений мог бы быть сфокусированным конкретно на задаче анализа. Курсовая работа могла бы включать структурированные аналитические техники, анализы сценариев и будущего, сетевую оценку и анализ военных способностей. Его задачей могла бы быть актуализация знаний и квалификации участников наиболее современными методами и исследованиями в этих дисциплинах. Возможно, более важным было бы то, что контакт участников с исследователями повысил бы их осведомленность об органических проблемах отдельных технологий и аналитических методов. Это способствовало бы критическому восприятию их собственной профессиональной методологии и увеличило бы их устойчивость против наиболее распространенных причин провала разведки. Такой блок был бы ближе всего к десятинедельному курсу для аналитиков разведки, предлагаемому Королевским колледжем, или курсовой работе по разведывательному анализу в университетах Джорджтауна или Мерсихерста.

В третьем блоке усиленного изучения специальных тем основной целью могла бы быть более традиционная коммуникация знаний - хотя и на последипломном уровне. В зависимости от своей профессиональной занятости студенты могли бы изучать набор курсов по избранным темам, как например, терроризм или киберпроблематика. Для них было бы полезно дискутировать на определенные темы с другими специалистами по этим вопросам и достичь понимания самых последних исследований в этой сфере за пределами аудитории.

31 National Intelligence University, Academic Catalogue 2013-2014 (Washington, D.C.: National Intelligence University, 2014), 37. 
Дипломная работа дала бы возможность студентам сочетать три пройденных аспекта как частей программы: основ, аналитических умений и избранных тем. Дипломную работу следовало бы сосредоточить на аспектах, соответствующих специфике разведывательного сообщества и таким образом, она способствовала бы повышению ценности данной институции.

В итоге можно сказать, что создание последипломной программы по разведывательным исследованиям в немецком университете вовсе не невозможная задача. Хотя все надо будет начинать с нуля, такая программа выиграла бы от отсутствия преобладающих школ и подходов в сфере разведывательных исследований и могла бы включать элементы международных программ, которые в наибольшей степени соответствовали бы потребностям студентов.

\section{Приложение}

\section{Бакалаврские степени}

- Бакалавр в сфере разведки, Национальный университет разведки (США)

- Дополнительная специализация в сфере разведки и международной безопасности, Университет Миссисипи (США)

- Основная специализация по разведывательным исследованиям, Университет Мерсихерста (США)

\section{Магистерские степени}

- $\quad$ Магистр по международным отношениям со специализацией по разведке, Карлтонский университет (Канада)

- Магистр в области разведки и международной безопасности, Кингс-колледж Лондона (Объединенное Королевство)

- Магистр в области разведки и стратегически исследований, Университет Аберистуита (Объединенное Королевство)

- $\quad$ Магистр в области разведки и исследований безопасности, Университет Брунеля (Объединенное Королевство)

- Магистр по разведывательным исследованиям, Университет Мерсихерста (США)

- Магистр по стратегической разведке, Институт мировой политики (США)

- Магистр по исследованиям в сфере безопасности с усиленным изучением разведки, Университет Джорджтауна (США)

\section{Аспирантские программы}

- $\quad$ Магистр по стратегической разведке, Национальный университет разведки (США) 
- Магистр по стратегической и технологической разведке, Национальный университет разведки (США)

Национальный университет разведки, Вашингтон, округ Колумбия (США) Разведка

www.n-iu.edu

\begin{tabular}{|l|l|}
\hline Степень & Бакалавр \\
\hline Продолжительность & 11 месяцев \\
\hline Кредиты & 57 кредита (86-114 ЕСТК) \\
\hline $\begin{array}{l}\text { особенный план/ } \\
\text { программы }\end{array}$ & $\begin{array}{l}\text { Основные модули } \\
\text { Выбираемые модули } \\
\text { Входные } \\
\text { требования }\end{array}$ \\
\hline
\end{tabular}

Описание: «Национальный университет разведки - бывший колледж военной разведки - является единственным получившим аккредитацию Разведывательного сообщества федеральным институтом, дающий образовательные степени. Бакалавр в области разведки (БР) - это программа четвертого года, которая позволяет студентам, проучившимся три года по бакалаврской программе или имевшим эквивалентные кредиты (минимум 80 семестриальных часов), получить степень бакалавра в области разведки. Программа направлена на стимулирование развития любознательных, ответственных выпускников, которые посвятят себя усовершенствованию национального Разведывательного сообщества».

\section{Основная программа (все)}

- Глобализация и ландшафт разведки

- Анализ разведывательной информации

- Активы и способности для сбора информации

- Природа конфликта и способности для конфликтов

- Разведка и стратегия национальной безопасности

- Культура и идентичность в эпоху глобализации

- Наука, технологии и разведка

- Аналитические методы

- Терроризм: корни и методологии

- Интеграция аналитиков и сборщиков информации

- Общая интеграция 


\section{Выбираемые дисциплины (Шесть)}

- Разведка: укрепление стабильности и мира

- Введение в секретность и дезинформацию

- Информационные операции

- Внутренняя безопасность и разведка

- Распространение оружий массового уничтожения

- Африка: проблемы разведки

- Ближний Восток: проблемы разведки

- Евразия: проблемы разведки

- Юго-западная Азия: проблемы разведки

- Восточная Азия: проблемы разведки

- Латинская Америка: геостратегические проблемы разведки

- Специальные темы в разведке

- Европа: проблемы разведки

Университет Миссисипи - Центр исследований по вопросам разведки и безопасности, Оксфорд, Миссисипи (США) Исследования по вопросам разведки и безопасности http://ciss.olemiss.edu/the-program/courses/

\begin{tabular}{|l|l|}
\hline Степень & Дополнительная специализация \\
\hline Продолжительность & Два года \\
\hline Кредиты & 18 кредитов $(27-36$ ЕСТК) \\
\hline $\begin{array}{l}\text { Учебный план/ } \\
\text { особенности } \\
\text { программы }\end{array}$ & \\
\hline $\begin{array}{l}\text { Обязательные модули } \\
\text { требовы }\end{array}$ & \\
\hline
\end{tabular}

Описание: «Специализация ИРБ направлена на подготовку незаурядных студентов Университета Миссисипи для занятия начальных должностей в Разведывательном сообществе Соединенных Штатов, частной индустрии, и анализе разведывательной информации в общественном секторе и в сфере безопасности. Разведывательное сообщество очень заинтересовано в таких ключевых компетенциях, как инжиниринг, критически важные языки (напр. арабский или китайский), компьютерные и физические науки, международные отношения и бизнес, и студентов, обучающихся в таких программах, поощряют поступать на эту специализацию. Однако, незау- 
рядные студенты любой специальности могут поступить на специализацию ИРБ».

Имеются студенты со специальностями: бухгалтерский учет, арабский язык, биология, химический инжиниринг, китайский язык, строительный инжиниринг, классические языки, уголовное право, экономика, английский, французский, геология, история, международные исследования, маркетинговые коммуникации, политология, психология, публичная политика, религиозные исследования, испанский язык.

\section{Обязательные модули}

- Введение в разведывательные исследования

- Продвинутая аналитика I

- Продвинутая аналитика II

- Проблемы национальной безопасности 21-го века

- Интернатура («Выпускной проект: эквивалентен дипломной работе, студенты применяют полученные на предыдущих курсах умения для осуществления проекта, который имеет практическую ценность для Разведывательного сообщества».)

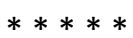

Университет Мерсихерста - Школа разведывательных исследований им. Тома Риджа, Эри, штат Пенсильвания (США)

Разведывательные исследования

http://www.theridgeschool.org/academics

\begin{tabular}{|c|c|}
\hline Степень & Бакалавр, специальность \\
\hline Продолжительность & Четыре года \\
\hline Кредиты & $\begin{array}{l}52 \text { кредита (78 - } 104 \text { ЕСТК) (только спе- } \\
\text { циальность) }\end{array}$ \\
\hline $\begin{array}{l}\text { Учебный план/ } \\
\text { особенности } \\
\text { программы }\end{array}$ & $\begin{array}{l}\text { Обязательные модули } \\
\text { Изучение специальных тем: язык или } \\
\text { компьютерные науки } \\
\text { Выбираемые модули }\end{array}$ \\
\hline $\begin{array}{l}\text { Входные } \\
\text { требования }\end{array}$ & $\begin{array}{l}\text { Стандартные университетские требова- } \\
\text { ния, открытая }\end{array}$ \\
\hline
\end{tabular}

Описание: «Миссией Школы разведывательных исследований и информационных наук им. Тома Риджа Университета Мерсихерста является подготовка выпускников с помощью разных форм, способных использовать разные источники данных и аналитические методы, которые в состоянии ру- 
ководить совместной разработкой высококачественных печатных и речевых аналитических разведывательных продуктов, которые на службе справедливого мира информируют людей, принимающих решения, таким образом воспитывая уважение к достойной работе и готовность служить другим.

Являясь первой неправительственной инициативой такого типа, бакалаврская степень в области разведывательных исследований есть уникальная мультидисциплинарная программа, целью которой является подготовка выпускников с квалификацией для занятия начальных должностей аналитиков в государственном и частном секторе. Являясь академически сложной дисциплиной, она сочетает основную часть в сфере свободных искусств с изучением иностранного языка или компьютерных наук, национальными и международными исследованиями, интернатурой и связанными с разведкой курсами для предоставления выпускникам высокого уровня аналитических умений».

\section{Основные модули (все)}

- Введение в анализ разведывательных данных

- Разведывательные методы и анализ

- Разведка и национальная безопасность

- Профессиональные коммуникации

- Разведка в бизнесе

- Написание текстов по вопросам разведки

- Разведка в сфере обеспечения правопорядка

- Стратегическая разведка

- Продвинутые компьютерные приложения или Введение в науку о данных

\section{Усиленное изучение языка или компьютерных наук}

Языковой вариант (3 курса разговорного языка)

Вариант компьютерные науки (выбрать три): Передовые компьютерные приложения, программирование, компьютерные операции, сети, анализ и проектирование информационных систем, менеджмент баз данных

\section{Выбираемые дисциплины в сфере разведки (выбираются три):}

- Американская военная история

- Разведка, вооруженные силы и война

- Культурная осведомленность для разведывательного анализа

- Специальные темы

- Улучшение анализа разведывательной информации

- Продвинутая разведка в сфере охраны правопорядка 
- Анализ киберугроз

- Продвинутая конкурентная разведка

- Терроризм

- История разведки

- Интернатура

\section{Выбираемые дисциплины вне сферы разведки (выбираются три):}

Пять курсов из общего каталога курсов, например, правосудие в Америке, экономика, история, статистика, геополитика, политическая теория.

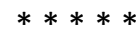

Карлтонский университет - Школа международных отношений им. Нормана Патерсона, Отава (Канада) Международные отношения со специализацией в сфере разведки и национальной безопасности http://graduate.carleton.ca/programs/international-affairs-masters/

\begin{tabular}{|c|c|}
\hline Степень & Магистр \\
\hline Продолжительность & Два года \\
\hline Кредиты & 5.0 кредитов (120 ECTS) \\
\hline $\begin{array}{l}\text { Учебный план/ } \\
\text { особенности } \\
\text { программы }\end{array}$ & $\begin{array}{l}\text { Основные модули (1.5 кредита) } \\
\text { Специализация в сфере разведки и национальной } \\
\text { безопасности ( } 1.5 \text { кредита) } \\
\text { Экзамен по языку } \\
\text { Дипломная работа ( } 2 \text { кредита) (можно заменить } \\
\text { четырьмя дополнительными специализирующими } \\
\text { модулями) }\end{array}$ \\
\hline $\begin{array}{l}\text { Входные } \\
\text { требования }\end{array}$ & Стандартные требования университета, открытая \\
\hline
\end{tabular}

Описание: «Школа международных отношений им. Нормана Патерсона (ШМОНП) была первостепенной для Канады программой в сфере международных отношений в течение 40 лет. У нас международная репутация учебного заведения, обеспечивающего интердисциплинарное и ориентированное на политику образование, необходимое для понимания все более сложной и глобализованной политической среды. Наша магистерская программа предлагает несколько областей специализации, сфокусированных на современных мировых событиях и политических проблемах, в том числе менеджмент конфликтов, безопасность, терроризм и разведка, международная торговля и финансы, международное управление и развитие. Вы можете выбрать одну из наших шести областей обучения, в ко- 
торой получить специализацию, или использовать программу как основу, сочетая ее с разными курсами, которые соответствуют вашим интересам».

Описание - специализация в сфере разведки и национальной безопасности: «Рассматриваются основные теории, концепции и вызовы в сфере национальной безопасности и разведки в контексте таких прикладных политических проблем, как терроризм, разоружение, гражданско-военные отношения и право».

\section{Основные модули (все)}

- Политический процесс и международные отношения

- Право и международные отношения

- Планирование и методы исследований для международных отношениях

- Статистический анализ для международных отношений

- Экономика для обороны и безопасности

\section{Специализация "Разведка и национальная безопасность» (3 из 7)}

- Разоружение, контроль над вооружениями и нераспространение

- Современная международная безопасность

- Разведка и международные отношения

- Разведка и национальная безопасность

- Политика и право в сфере национальной безопасности

- Терроризм и международная безопасность

- Избранные темы в сфере разведки и национальной безопасности

\section{Успешная сдача экзамена на владение второго языка}

\section{Дипломная работа на получение степени магистра}

Кингс-колледж, кафедра военных исследований, Лондон (Объединенное Королевство)

Исследования в сфере разведки и международной безопасности

www.kcl.ac.uk/prospectus/graduate/intelligence-and-international-security

\begin{tabular}{|l|l|}
\hline Степень & Магистр \\
\hline Продолжительность & Один год \\
\hline Кредиты & 180 кредитов (90 РСТК) \\
\hline Учебный план/ & Основной модуль (40 кредитов) \\
особенности & Выбираемые модули (80 кредитов) \\
программы & Дипломная работа (60 кредитов) \\
\hline
\end{tabular}




\begin{tabular}{l|l}
\hline $\begin{array}{l}\text { Входные } \\
\text { требования }\end{array}$ & Стандартные требования университета, открытая \\
\hline
\end{tabular}

Описание: “'Разведка и международная безопасность' занимается изучением тенденций, которые продолжают формировать разведку и развитие геополитики в 21 веке. Студенты развивают осведомленность о формах, в которой проблемы разведки проявляют себя в вопросах безопасности во время мира и во время войны. Понимание этических дилемм, связанных с разведывательной деятельностью».

\section{Основной модуль}

- Разведка в мирное время и во время войны

\section{Выбираемые модули (2 из 34)}

- Проблемы безопасности Афганистана и Южной Азии

- Искусство и война

- Гражданская война в США 1861-1865

- Комплексные политические чрезвычайные ситуации, здравоохранение и безопасность

- Превенция конфликтов и строительство мира

- Симулирование конфликтов

- Конфликты, развитие и ислам в России, Кавказе и Центральной Азии

- Современная британская политика в сфере обороны

- Современные проблемы в сфере науки и безопасности

- Дипломатия

- Безопасность Восточной Азии

- Этика в международных отношениях

- Европейская (не)безопасность

- Европейская безопасность

- Миграция и права человека

- Интердисциплинарные подходы к (не)безопасности

- Международная политика на Ближнем Востоке

- Исследование конфликтов в глобальной политике

- СМИ и разведка

- Распространение ракет

- Национализм и безопасность

- Природные ресурсы и конфликты

- Разведка с использованием открытых источников

- Мир и справедливость

- Распространение и международная безопасность 
- Пропаганда

- Отчеты о войнах

- Наука и безопасность в вопросах ядерного и биологического оружия

- Проблемы безопасности в бывших советских республиках

- Ведение современной войны

- Эволюция повстанческого движения

- СРК и британская разведка

- Распространение оружия

- Внешняя политика США

Университет Аберистуита, кафедра международной политики, Аберистуит (Объединенное Королевство) Разведывательные исследования (подготовка исследователей) http://courses.aber.ac.uk/postgraduate/intelligence-studies-mastersspecialist/

\begin{tabular}{|l|l|}
\hline Степень & Магистр \\
\hline Продолжительность & Один год \\
\hline Кредиты & 180 кредитов (90 ЕСТК) \\
\hline $\begin{array}{l}\text { Учебный план/ } \\
\text { особенности } \\
\text { программы }\end{array}$ & $\begin{array}{l}\text { Основные модули (80 кредитов) } \\
\text { Выбираемые модули (20 кредитов) } \\
\text { Факультативные модули (20 кредитов) } \\
\text { Дипломная работа (60 кредитов) }\end{array}$ \\
\hline $\begin{array}{l}\text { Входные } \\
\text { требования }\end{array}$ & \begin{tabular}{l} 
Стандартные требования университета, открытая \\
\hline
\end{tabular} \\
\hline
\end{tabular}

Описание: «Эта инновационная магистерская схема направлена на облегчение развития критически важной осведомленности о состоянии теории и практики в сфере разведывательных исследований в сочетании с глубоким пониманием современного использования силы в международных отношениях. В число изучаемых проблем и дебатов входят конкурентные подходы и концептуальные дебаты, касающиеся природы и определения разведывательных и стратегических исследований и их взаимные отношения».

\section{Основные модули (все)}

- Разведка, безопасность и международная политика 1900-1945

- Разведка, безопасность и международная политика после 1945 года 
- Политические, социальны и исторические исследования: философия, методы и применение

- Принципы планирования исследований

- Сбор и анализ количественных данных

- Сбор и анализ качественных данных

\section{Выбираемые модули (минимум один):}

- Исследования современных критически важных стратегических проблем безопасности

- Британские антиповстанческие военные действия в двадцатом веке

- Цифровая связанность: цифровые пространства и кибермиры

\section{Дипломная работа}

$$
* * * * *
$$

Университет Брунеля, Центр исследований по вопросам разведки и безопасности им. Брунеля, Лондон (Объединенное Королевстве)

Разведка и безопасность

www.brunel.ac.uk/courses/postgraduate/intelligence-and-security-studies-ma

\begin{tabular}{|l|l|}
\hline Степень & Магистр \\
\hline Продолжительность & Один год \\
\hline Кредиты & 180 кредитов (90 ЕСТК) \\
\hline $\begin{array}{l}\text { Учебный план/ } \\
\text { особенности } \\
\text { программы }\end{array}$ & $\begin{array}{l}\text { Основные модули (120 кредита) } \\
\text { Дипломная работа (60 кредитов) }\end{array}$ \\
\hline $\begin{array}{l}\text { Входные } \\
\text { требования }\end{array}$ & Стандартные требования университета, открытая \\
\hline
\end{tabular}

Описание: «Вопросы политики разведывательной деятельности и безопасности являются одной из самых быстро расширяющихся областей академического и общественного интереса, особенно после '9/11' и войн в Ираке и Афганистане. Сегодня в большей степени, чем прежде, национальные правительства, международные агентства и большинство крупных международных корпораций установили наличие потребности в персонале с глубоким пониманием вопросов разведки и безопасности, которые также обладают первоклассными умениями для проведения исследований и оценок.

Преподаваемая учеными с международной известностью Центра исследований по вопросам разведки и безопасности, подкрепляемая опытом практиков там, где это нужно, магистерская программа по разведке и 
безопасности предлагает возможность для практической, ориентированной на политику, учебы по вопросам разведки, применимой для всего частного и общественного сектора по всему миру».

\section{Основные модули (все)}

- Концепции разведывательной деятельности: вопросы и институции

- История разведки: провалы и успехи

- Анализ разведывательных данных и принятие решений

- Современные угрозы и методология анализа

\section{Дипломная работа}

$$
* * * * *
$$

Университет Мерсихерста, Школа исследований по вопросам разведки имени Тома Риджа, Эри, штат Пенсильвания (США)

Прикладная разведка

http://www.theridgeschool.org/academics

\begin{tabular}{|c|c|}
\hline Степень & Магистр \\
\hline Продолжительность & Два года \\
\hline Кредиты & 34 кредита (51-68 ЕСТК) \\
\hline $\begin{array}{l}\text { Учебный план/ } \\
\text { особенности } \\
\text { программы }\end{array}$ & $\begin{array}{l}\text { Основные модули (21 кредита) } \\
\text { Выбираемые модули (9 кредитов) } \\
\text { Дипломная работа (3 кредита) }\end{array}$ \\
\hline $\begin{array}{l}\text { Входные } \\
\text { требования }\end{array}$ & Стандартные требования университета, открытая \\
\hline
\end{tabular}

Описание: «Миссией Школы исследований по вопросам разведки и информационных наук при Университете Мерсихерста является подготовка выпускников с магистерской степенью с использованием различных форм, которые, применяя умения использовать разнообразные источники и технологии анализа, могут руководить совместной разработкой письменных и речевых аналитических разведывательных продуктов, которые на пользу всему справедливому миру, информируют людей, принимающих решения, таким образом утверждая высокое мнение о почтенности в работе и готовности служить другим.

В программе на получение магистерской степени по прикладной разведывательной деятельности подчеркнуто значение применения теории разведки в ряде дисциплин из сферы национальной безопасности, вооруженных сил, охраны правопорядка и конкурентной разведки. Программа Мерсихерста сфокусирована на разведке в качестве процесса, используя (сначала неструктурированную) информацию из всех источников, направ- 
ленной наружу, которая предназначена для снижения уровня неопределенности для людей, принимающих решения. С учетом этой направленности, курсовая работа сосредоточена на развитии углубленных исследовательских способностей, умелом использовании техники и методологии анализа, составления сжатых аналитических текстов и эффективного инструктирования. Развитие этих аналитических умений в сочетании с пониманием значения теории и истории в сфере разведки дает возможность готовить выпускников с магистерской степенью, которые в состоянии осуществлять руководство основанной на знаниях рабочей средой будущего».

\section{Основные модули (все)}

- Методы исследований в разведке

- Теория и практическое применение разведки

- Конкурентная разведка

- Разведка в сфере охраны правопорядка

- Коммуникации в разведке

- Современное лидерство в разведке

- Менеджмент стратегического анализа разведывательной информации

\section{Выбираемы модули (три)}

- Продвинутые методы анализа

- Анализ киберугроз

- Сравнительная история разведки

- Разведывательная поддержка выбора целевой аудитории

- Геопространственная разведка

- Анализ в финансовой разведке

- Разведка и бизнес стратегия

- Анализ данных для частного сектора

- Выпускной семинар: национальная безопасность

- Исследования по вопросам терроризма

- Разведка, вооруженные силы и война

- Политика и практика контршпионажа

- Избранные темы по разведке

- Большая стратегия: стратегическое планирование и стратегическая разведка

- Анализ в сфере нераспространения

- Интернатура

\section{Дипломная работа}




\section{Институт мировой политики, Вашингтон, округ Колумбия Исследования по вопросам стратегической разведки} http://www.iwp.edu/programs/degree/master-of-arts-in-strategic-intelligencestudies

\begin{tabular}{|c|c|}
\hline Степень & Магистр \\
\hline Продолжительность & Два года \\
\hline Кредиты & 52 кредита (78 - 104 ЕСТК) \\
\hline $\begin{array}{l}\text { Учебный план/ } \\
\text { особенности } \\
\text { программы }\end{array}$ & $\begin{array}{l}\text { Основные модули ( } 36 \text { кредитов) } \\
\text { Выбираемые/Усиленное изучение (16 кредитов) } \\
\text { Без дипломной работы }\end{array}$ \\
\hline $\begin{array}{l}\text { Входные } \\
\text { требования }\end{array}$ & Стандартные требования университета, открытая \\
\hline
\end{tabular}

Описание: «Программа на получение степени магистра по специальности исследования по вопросам стратегической разведки предназначена для студентов, которые ориентируются на карьеру в сфере разведки, а также для профессионалов, на чьи агентства или клиентов возложена ответственность за получение и интерпретацию разведывательных данных. В программу включены курсы по таким фундаментальным разведывательным дисциплинам, как анализ и эпистемология, сбор разведданных и дезинформация. Программа дает студентам все инструменты и знания, необходимые сегодня и возможно завтра, которые нужны для профессионального успеха в этой сфере».

\section{Основные модули (все)}

- Экономика для разработчиков внешней политики

- География и стратегия

- Основополагающие принципы и внешняя политика

- Международные отношения, государственность и интегрированная стратегия

- Моральная традиция Запада и мировая политика

- Разведка и политика

- Сбор разведывательных данных или Роль и значение агентурной разведки или Разведка США во времена Холодной войны и после нее

- Оценочный анализ разведывательной информации и эпистемология

- Борьба с повстанческими движения в демократическом обществе

- Внешняя пропаганда, восприятия и политика или Публичная дипломатия и политическая война или Политическая война: прошлое, настоящее и будущее 
Выбираемые модули (в общей сложности четыре, как минимум по одному в каждой специализации)

Специализация "Искусство разведки»

- Американская разведка и защитная безопасность: расширенный семинар

- Культурологическая разведка для стратегии и анализа

- Вызов контрразведки: энигмы и выгоды от перебежчиков

- Прогнозирование и анализ политического риска

- Основы внутренней безопасности

- Военная разведка в современной войне

- Неожиданность, предупреждение и обман

- Технология, разведка, безопасность, государственность

- Ядерная политика и политика нераспространения США

Специализация "Контрразведка и иностранная разведка»

- Доктрина вражеской угрозы Аль-Каиды

- Изучение конкретных случаев контрразведывательных операций

- Сравнительные системы разведки: иностранные культуры разведки и безопасности

- Контртерроризм и демократии

- Кибер государственность

- Основы внутренней безопасности

- История контрразведки ФСБ

- Шпионы, подрывная работа, терроризм и операции влияния

- Терроризм

$$
* * * * *
$$

Университет Джорджтауна, Школа дипломатической службы, Вашингтон, округ Колумбия (США)

Исследования в сфере безопасности с усиленным изучением разведки https://css.georgetown.edu/ssp

\begin{tabular}{|c|c|}
\hline Степень & Магистр \\
\hline Продолжительность & Два года \\
\hline Кредиты & 36 кредитов США (54 - 72 ЕСТК) \\
\hline $\begin{array}{l}\text { Учебный план/ } \\
\text { особенности } \\
\text { программы }\end{array}$ & $\begin{array}{l}\text { Основные модули (6 кредитов) } \\
\text { Усиленное изучение разведки (12 кредитов) } \\
\text { Выбираемые модули (6 кредитов) } \\
\text { Исследовательский семинар (дипломная работа) }\end{array}$ \\
\hline
\end{tabular}




\begin{tabular}{|l|l|}
\hline & $\begin{array}{l}\text { (6 кредитов) } \\
\text { Экзамен (6 кредитов) }\end{array}$ \\
\hline $\begin{array}{l}\text { тходные } \\
\text { требования }\end{array}$ & Стандартные требования университета, открытая \\
\hline
\end{tabular}

Описание: «Магистерский учебный план Программы исследований по вопросам безопасности (ПИБ) дает студентам солидный фундамент по концепциям, истории и сущности проблем национальной и международной безопасности; а также способность вести оригинальные исследования и анализировать современные проблемы безопасности».

Описание специализации по разведке: «В этой специализации студенты приобретают понимание практических измерений разведки, в том числе цикла разведки, разведывательных дисциплин, проблем сбора и анализа разведывательной информации, тайных действий и связи между разведкой и политикой. Особое внимание уделяется внутренней разведке, военной разведке и разведывательным операциям и культурам других стран. Студенты также знакомятся с такими важными концептуальными проблемами, как роль разведки в демократическом обществе, вопросы надзора и подотчетности, бюджета разведки как части общего оборонного бюджета и сложности секретности. В дополнение к помощи, которую оказывает эта специализация подготовке студентов к карьере в разведывательном сообществе, она также занимается разведывательными проблемами в военных, государственных агентствах или связанных с государством индустриями».

\section{Основные модули}

- Теория и практика безопасности

- Большая стратегия и военные операции

\section{Специализация - разведка}

Основной модуль

- Теория и практика разведки (обязательный)

Выбираемые специализирующие модули (3 из 22)

- Сравнение разведывательных служб

- Секретные операции/контрразведка

- Анализ подрывной деятельности: теория, методы и технология

- Ключевые проблемы в разведывательной политике

- Критическое мышление в сфере разведки и политики

- Разведка и вооруженные силы

- Операции агентурной разведки 
- Внутренняя разведка

- Принятие решений в стрессовой среде

- Анализ подрывной деятельности

- Структурированные аналитические техники для анализа разведывательной информации

- Проблемы безопасности в Южной Азии

- Проблемы безопасности на Ближнем Востоке и в Персидском заливе

- Политика европейской безопасности

- Китай и его вооруженные силы

- Проблемы безопасности в Южной Америки

- Политика силы в Большом Ближнем Востоке

- Война на Ближнем Востоке

- Евразия и Россия: новая динамика безопасности

- Проблемы безопасности в Африке

- Глобальный терроризм: Европа до Средиземноморья

- Вызовы стабильности: Южная/Юго-восточная Азия

Выбираемые модули (минимум два)

Исследовательский семинар (дипломная работа)

Национальный университет разведки, Вашингтон, округ Колумбия (США) Стратегическая разведка

www.n-iu.edu

\begin{tabular}{|l|l|}
\hline Степень & Магистр \\
\hline Продолжительность & 11 месяцев \\
\hline Кредиты & 43 кредита (70-90 ЕСТК) \\
\hdashline Учебный план/ & $\begin{array}{l}\text { Основные модули (15 кредитов) } \\
\text { оребенности } \\
\text { программы }\end{array}$ \\
\hdashline $\begin{array}{l}\text { Выбираемые модули (18 кредитов) } \\
\text { Дипломная работа (7 кредитов) }\end{array}$ \\
\hline требоные & \begin{tabular}{l} 
Только служащие Вооруженных сил США и со- \\
трудники федеральных ведомств, допуск к клас- \\
\hline сифицированной информации
\end{tabular} \\
\hline
\end{tabular}

Описание: «Национальный университет разведки - бывший Колледж военной разведки - является единственной, получившей аккредитацию Разведывательного сообщества, федеральной институцией, дающей образо- 
вательные степени. Основной кампус находится в Вашингтоне, округ Колумбия, но также располагает Академическими центрами по всему миру. Учебный план по магистерской специальности «Стратегическая разведка» интегрирует опубликованные компетентности ДНР (Директора национальной разведки), знания и умения в рамках основного конструкта университета. Студенты этой программы проходят основные курсы для введения в стратегическую природу анализа разведывательной информации. Студенты по СР изучают человеческие элементы разведывательной деятельности, рассматривая политические, военные, экономические, технические и культурные темы, связанные с разведкой. Исследования в их дипломной работе должны касаться темы, имеющей значение для РС [Разведывательного сообщества]».

\section{Основные модули}

- Проблемы глобализации и разведки

- Социальный анализ и спектр конфликта

- Аргументация и анализ в разведке

- Составной глаз: сбор разведывательной информации

- Разведка и политика национальной безопасности

\section{Требования программы (оба или одно из двух)}

- Наука и технологии

- Стратегия деконструкции

\section{Выбираемые модули (6 в общей сложности)}

Стратегическая область: "Военная стратегия: разведка во время боевых действий и в мирное время»

- Асимметричная война: будущие стратегии

- Планирование и разведка для совместных операций

- Операции по поддержанию мира и стабильности

- Взаимодействие с международными партнерами

- Учение по преодолению стратегического кризиса

Стратегическая область: «Проблемы и менеджмент разведывательного сообщества»

- Лидерство и менеджмент в Разведывательном сообществе

- Менеджмент разведывательных ресурсов

- Этика и разведка

- Разведка и национальная безопасность

- Продвинутый сбор разведывательной информации

- Ресурсы, методы и операции электронной разведки 
- Продвинутые методы анализа разведданных

- Транснациональные вопросы в криптографической среде

- Тайные операции

- Современные криптографические проблемы

- Анализ оперативных способностей

- Геопространственная разведка: ситуационная осведомленность или преимущество при принятии решений

- Сравнительный контрразведывательный анализ

Стратегическая область: "Транснациональные угрозы: проблемы разведки»

- Экономика и разведка

- Корни терроризма

- Среда транснациональных угроз

- Разведка в защиту отечества

- Борьба с угрозой терроризма

- Контрразведка

Стратегическая область: «Геостратегическая среда: заполнение пробелов разведки»

- Ислам и современный мир

- Африка: геостратегические проблемы разведки

- Северо-восточная Азия: геостратегические проблемы разведки

- Проблемы разведки в Южной Азии

- Китай в будущем

- Европа: партнер в разведке и объект анализа

- Латинская Америка: геостратегические проблемы разведки

- Ближний Восток: геостратегические проблемы разведки

- Социокультурная разведка

- Россия: геостратегические проблемы разведки

- Кавказ

- Ближнее зарубежье

- Иран: геостратегические проблемы разведки

\section{Требования к дипломной работе}

- Методология и планирование дипломной работы

- Предложение темы дипломной работы

- Проведение исследований по дипломной работе

- Завершение дипломной работы 


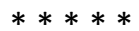

Национальный университет разведки, Вашингтон, округ Колумбия (США) Стратегчческая и технологическая разведка www.n-iu.edu

\begin{tabular}{|l|l|}
\hline Степень & Магистр \\
\hline Продолжительность & 11 месяцев \\
\hline Кредиты & 43 кредита (70-90 ЕСТК) \\
\hline Учебный план/ & $\begin{array}{l}\text { Основные модули (15 кредитов) } \\
\text { особенности } \\
\text { программы }\end{array}$ \\
\hline Вребования программы (3 кредита) \\
Выбираемые модули (18 кредитов) \\
Дипломная работа (7 кредитов) \\
требования & $\begin{array}{l}\text { Только служащие Вооруженных сил США и со- } \\
\text { трудники федеральных ведомств, допуск к } \\
\text { классифицированной информации }\end{array}$ \\
\hline
\end{tabular}

Описание: «Национальный университет разведки - бывший Колледж военной разведки - является единственной, получившей аккредитацию Разведывательного сообщества, федеральной институцией, дающей образовательные степени. Магистерская программа по технологической разведке готовит студентов к пониманию влияния технологических перемен на национальную безопасность и разведку».

\section{Основные модули (все)}

- Проблемы глобализации и разведки

- Социальный анализ и спектр конфликта

- Аргументация и анализ в разведке

- Составной глаз: сбор разведывательной информации

- Разведка и политика национальной безопасности

\section{Требования программы (оба/или одно из двух)}

- Продвинутые методы анализа разведывательной информации

- Наука и технологии

Специализация (в общей сложности 6 курсов, четыре курса в одной специализации для зачета специализации)

Специализация: «Оружия массового уничтожения»

- ОМУ терроризм

- Противодействие распространению 
Подъем учебных программ по вопросам разведки: модель для Германии?

- Биологическая угроза

- Ядерная угроза

- Химическая угроза и угроза взрывчатых веществ

- Продвинутые конвенциональные и неконвенциональные оружия

- Учения по преодолению стратегического кризиса

Специализация: «Информационные операции и киберразведка»

- Информационное могущество и национальная безопасность

- Пропаганда, убеждение и влияние

- Киберразведка

- Иностранные информационные и кибер стратегии

- Киберугроза

- Социальные сети и разведка

- Расширенный семинар по информационному могуществу

- Эксплуатация и расширенный анализ киберданных

- Среда сетевых операций - участие в сетевых операциях

- Информационное влияние и обман

- Продвинутая киберразведка

Специализация: “Новопоявляющиеся и прорывные технологии»

- Расширенный курс по науке и технологии

- Расширенный курс по конвенциональным и неконвенциональным оружиям

- Экономика технологии

- Разбор конкретных примеров по трансферту технологий

- Оценка уязвимости инфраструктуры

- Учение по преодоления стратегического кризиса

Специализация: «Геостратегические ресурсы и геостратегическая среda»

- Разведка и меняющаяся глобальная среда ресурсов

- Геология и разведка

- Ядерные и другие альтернативные источники энергии

- Системы производства и распределения электричества

- Учение по преодолению стратегического кризиса

- Экономика технологий

- Оценка уязвимости инфраструктуры 
Специализация «Воспрещение и маскировка в разведывательной деятельности за границей»

- Введение в воспрещение и маскировку: история, концепции, проблемы и следствия

- Воспрещение и маскировка: психологические/ культурологические аспекты и принятие решений в сфере национальной безопасности

- Воспрещение и маскировка: противники, организации, деятельности и контрмеры

- Воспрещение и маскировка: ремесло, инструменты и методология

\section{Требования к дипломной работе}

- Методология и планирование дипломной работы

- Предложение темы дипломной работы

- Проведение исследований по дипломной работе

- Завершение дипломной работы

\section{6 авторах}

Профессор доктор Уве М. Боргофф является вице-президентом Университета Бундесвера в Мюнхене и директором Кампусного центра продвинутых исследований, университетского центра профессионального образования. Доктор Бригита Джерадж и Алесандро Шефлер Корвайа являются исполнительными ассистентами и научными сотрудниками при Кампусном центре перспективных исследований. 